\title{
PENGEMBANGAN PRODUK MAKANAN COKELAT BERBASIS PREFERENSI KONSUMEN
}

\section{PRODUCT DEVELOPMENT OF CHOCOLATE FOOD BASED ON CUSTOMER PREFERENCE}

\author{
Humiras Hardi Purba ${ }^{1)^{*}}$, M. Syamsul Maarif ${ }^{2)}$, Indah Yuliasih" ${ }^{3)}$, Aji Hermawan') \\ ${ }^{1)}$ Departemen Teknik Industri, Universitas Mercu Buana \\ J1. Meruya Selatan No.1. Jakarta Barat, Indonesia 11650 \\ E-mail: hardipurba@yahoo.com \\ ${ }^{2)}$ Sekolah Bisnis, Institut Pertanian Bogor J1. Raya Pajajaran, Bogor 16151, Indonesia \\ ${ }^{3)}$ Departemen Teknologi Industri Pertanian, Fakultas Teknologi Pertanian, Institut Pertanian Bogor, Indonesia \\ Makalah: Diterima 8 Januari 2018; Diperbaiki 1 April 2018; Disetujui 12 April 2018
}

\begin{abstract}
The cocoa commodity is very important to the Indonesian economy and has the potential to be the main producer of chocolate products in the world. The consumption level of national chocolate per capita of $0.3 \mathrm{~kg} /$ person/year with an increasing trend, is a good market opportunity including for small and medium enterprises (SME) chocolate processing industry. The objective of this research was to develop the quality of local chocolate products based on consumer preference to be more competitive in the domestic market. In this study, interviews and filling questionnaires to consumers who regularly eat chocolate foods, in order to determine the level of importance and level of customer satisfaction, were conducted. There were eleven sensory attributes that were asked to consumers where consumers provide less satisfied assessment of chocolate products consumed were taste, texture, aroma, product appearance, portion, variety, freshness, health, packaging, price fairness, and discount. The result of calculation and analysis of IPA (importance performance analysis) found that attributes that need development were those in quadrant A, i.e. taste, texture, aroma, product apperance, variety, freshness, health, and packaging.
\end{abstract}

Keywords:chocolate, cocoa, customer preference, importance performance analysis

\section{ABSTRAK}

Komoditas kakao sangat penting bagi perekonomian Indonesia dan memiliki potensi untuk menjadi produsen utama produk cokelat di dunia. Tingkat konsumsi cokelat nasional per kapita $0,3 \mathrm{~kg} /$ orang / tahun dengan tren yang meningkat, merupakan peluang pasar yang baik termasuk untuk industri pengolahan cokelat kecil dan menengah (UKM). Tujuan penelitian ini adalah untuk mengembangkan kualitas produk cokelat lokal berdasarkan preferensi konsumen, agar lebih kompetitif di pasar domestik. Dalam penelitian ini, dilakukan wawancara dan pengisian kuesioner kepada konsumen yang rutin mengonsumsi makanan cokelat, guna menentukan tingkat kepentingan dan tingkat kepuasan pelanggan. Ada sebelas atribut sensorik yang diminta kepada konsumen di mana konsumen memberikan penilaian kurang puas dari produk coklat yang dikonsumsi yaitu: taste, texture, aroma, product appearance, portion, variety, freshness, health, packaging, price fairness, dan discount. Hasil perhitungan dan analisis IPA (importance performance analysis) menemukan bahwa atribut yang perlu dikembangkan adalah yang berada pada kuadran A yaitu: taste, texture, aroma, product appearance, variety, freshness, health, dan packaging.

Kata kunci: cokelat, importance performance analysis, kakao, preferensi konsumen

\section{PENDAHULUAN}

Kakao merupakan komoditas penting bagi dunia global karena sebagai bahan utama produk cokelat, kakao memiliki rasa dan aroma yang tidak tergantikan oleh komoditas yang lain (Hii et al., 2010). Masyarakat di seluruh dunia saat ini menikmati cokelat dalam ribuan bentuk yang berbeda, mengkonsumsi lebih dari 3 juta ton biji kakao setiap tahun. Berdasarkan perhitungan organisasi kakao internasional (ICCO), nilai transaksi komoditas kakao mencapai \$US10 milyar per tahun selama periode tahun 2011/2012. Nilai ritel penjualan cokelat selama tahun 2012 tercatat sebesar US $\$ 107$ milyar (ICCO, 2014). Banyak perusahaan yang memulai bisnis keluarga kecil dengan mengandalkan produksi cokelat individual, tumbuh menjadi perusahaan besar dengan menggunakan metode produksi industri (Alberts dan Cidell, 2006).

Setiap negara penghasil biji kakao di dunia memiliki sifat yang khas apabila dilihat dari rasa (flavor) dan kandungan minyak (fat) di dalamnya. Flavor merupakan atribut kualitas penting yang menentukan akseptabilitas biji kakao dan produk kakao seperti cokelat (Kongor et al., 2016). Biji kakao yang berasal dari benua Afrika seperti dari Pantai Gading, Ghana, dan Nigeria memiliki tingkat flavor yang tinggi, dengan volume produksi yang besar, sedangkan tanaman kakao yang berada di kawasan Asia Tenggara seperti Indonesia dan Malaysia memiliki sifat yang berbeda, dominan dengan kandungan lemak (fat) yang tinggi, tetapi flavor berada di tingkat relatif rendah (Panlibuton 
dan Meyer, 2004). Rasa khas dari biji kakao tidak hanya tergantung pada varitas tanaman, tetapi juga kontur tanah, suhu lingkungan, serta jumlah sinar matahari dan hujan yang diterima (Verna, 2013).

Othman et al. (2007) melaporkan bahwa asal geografis suatu negara penghasil kakao menunjukkan perbedaan tingkat kapasitas antioksidan tergantung pada jenis ekstraksi pelarut yang digunakan, dimana antioksidan tertinggi yang diamati dimiliki oleh biji kakao dari Ghana diikuti oleh Pantai Gading, Malaysia dan Sulawesi. Biji kakao yang mengandung antioksidan flavonoid berguna untuk menahan radikal bebas bermanfaat untuk kesehatan, karena cokelat kaya akan kandungan antioksidan yaitu fenol dan flavonoid. Efek menguntungkan dari flavonoid adalah, anti alergi, anti tumor, merangsang fungsi kognitif, modulasi aktivitas estrogen, anti virus, antioksidan (McShea et al., 2008; Verna, 2013; Bordiga et al., 2015). Penelitian menunjukkan bahwa dengan adanya antiosidan akan mampu untuk menangkap radikal bebas dalam tubuh.

Masyarakat dunia sudah semakin menyadari bahwa selain sebagai bahan pangan, makanan berbasis kakao juga berfungsi bagi kesehatan tubuh. Beberapa studi telah menunjukkan secara nyata bahwa seseorang yang mengonsumsi kakao atau cokelat dapat mengurangi resiko penyakit cardiovascular (Osakabe et al.,1998; Keen, 2001). Selanjutnya, Erukainure et al. (2010), dalam penelitiannya membuktikan bahwa kandungan energi cokelat, setiap $50 \mathrm{~g}$ terdapat $265 \mathrm{kkal}$, setara dengan $10 \%$ energi harian laki-laki dan $14 \%$ bagi energi harian wanita. Merujuk pada penelitian Afoakwa (2008), membuktikan bahwa secara umum dark chocolate mengandung $63,5 \%$ karbohidrat, $28 \%$ lemak, dan $5 \%$ protein. Milk chocolate terdiri dari $56,9 \%$ karbohidrat, 30,7\% lemak, $7,7 \%$ protein. Tipe produk cokelat lainnya, white chocolate memiliki 58,3\% karbohidrat dan 30,9\% lemak, serta $8 \%$ kadar protein. Diyakini secara khusus dark chocolate dapat memperkuat fungsi hati manusia dan dapat menurunkan tekanan darah.Banyaknya riset yang memublikasikan manfaat kandungan kimia yang terdapat pada cokelat, secara tidak langsung mempromosikan dark chocolate tidak lagi hanya produk pangan biasa, namun juga memiliki bermanfaat bagi kesehatan (Keen, 2001).

Proses pengolahan dapat memiliki dampak besar pada tingkat polifenol yang dipertahankan dalam biji kakao dan produk turunannya. Produk turunan kakao sangat beragam sebagai makanan (food), minuman (beverages), farmasi dan kosmetik serta produk lainnya. Hasil berbagai penelitian telah dilaporkan terkait kontribusi kakao polifenol bagi kesehatan manusia, namun pemahaman penuh masih diperlukan dalam aspek bioavailabilitas polyophenols kakao berkaitan dengan penyerapan yang tepat, distribusi, metabolisme dan ekskresi polyophenols dalam tubuh manusia (Hii et al., 2010). Beberapa efek kesehatan dari kandungan biji kakao telah banyak dipertimbangkan, termasuk meningkatkan fungsi jantung, meningkatkan rangsangan dari sistem saraf, memfasilitasi proses pencernaan, dan meningkatkan fungsi ginjal dan usus (Corti et al., 2009). Pengaruh kakao terhadap kesehatan termasuk efeknya terhadap kesehatan jantung dan pembuluh darah harus dicermati dengan hati-hati antara biji kako dengan cokelat, dimana produk olahan cokelat sudah tidak murni lagi kandungan biji kakao, tetapi sudah dicampur dengan gula, susu, dan zat lainnya yang terkadang kontra produktif dan memberikan efek yang kurang baik bagi kesehatan (Corti et al., 2009). Menurut Gilbert (2006), industri kakao lebih rumit karena produk akhir sebagai produk cokelat merupakan penggabungan berbagai bahan baku lain seperti gula, susu dan aneka bahan lainnya dengan porsi beragam sebagai bahan tambahan.

Syahruddin dan Kalchschmidt (2011) dalam studinya menjelaskan bahwa selama periode tahun 1997-2006 konsumsi cokelat di seluruh dunia bertumbuh sebesar $14 \%$ setiap tahunnya. Konsumsi global cokelat didominasi oleh Eropa sebesar $49 \%$ dan Amerika Utara sebanyak 22\% dengan konsumsi rata-rata 3,2 kg per orang pada tahun 2006. Setiap negara masih memiliki preferensi sendiri dan campuran khusus untuk aneka makanan dan minuman berbasis kakao. Swiss merupakan negara dengan tingkat konsumsi cokelat terbesar di dunia dengan $9 \mathrm{~kg}$ per kapita. Jepang mengonsumsi 2,0 kg per kapita. Negara Singapura $0,5 \mathrm{~kg}$ perkapita, sedangkan Indonesia masih relatif kecil yaitu $0,3 \mathrm{~kg}$ per kapita meningkat dari tahun-tahun sebelumnya yang hanya 0,01 kg (ICCO, 2015; FAO, 2015; Euromonitor, 2016). Konsumsi perkapita cokelat beberapa Negara disajikan pada Gambar 1.

Posisi Indonesia sangat strategis dimana menempati urutan ketiga dunia produsen kakao dengan produksi 593.331 ton (2015) dan 656.817 ton pada tahun 2016 dengan nilai ekspor masingmasing sebesar US\$469,005,000 (2014), US\$293,780,000 (2015) dan pada tahun 2016 dengan nilai US\$242,496,000 (Direktorat Jenderal Perkebunan, 2016). Nilai tambah kakao menjadi lebih besar setelah melalui proses pengolahan menjadi produk akhir (end product) cokelat pada industri hilir. Konsumsi perkapita cokelat nasional yang saat ini hanya sebesar $0,3 \mathrm{~kg} /$ orang/tahun dan diprediksi akan terus bertumbuh, maka pengembangan industri hilir cokelat untuk pangsa pasar nasional menjadi sangat penting. Pengembangan agroindustri hilir sangat strategis, karena memberikan penciptaan output dan kesempatan kerja yang besar (Pratiwi et al., 2017) 


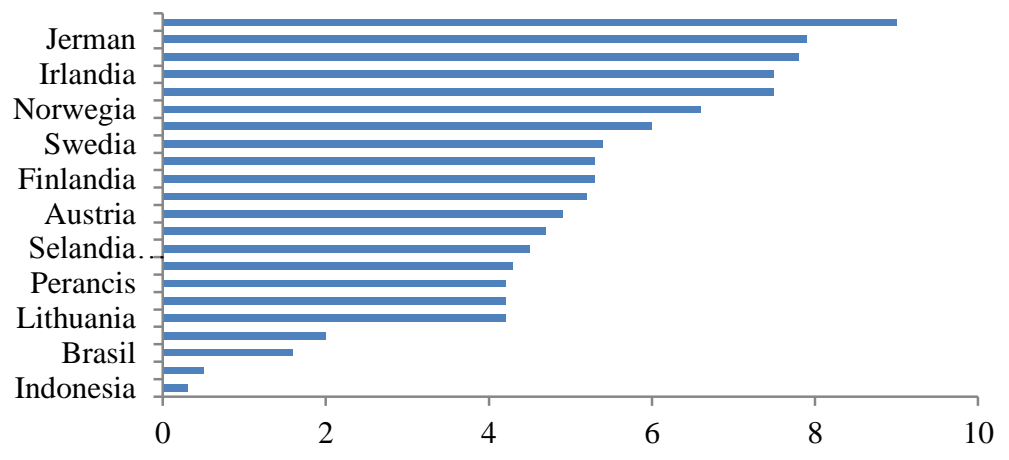

Gambar 1. Konsumsi perkapita cokelat beberapa negara tahun 2014 (Sumber: ICCO, 2015; Euromonitor, 2016; FAO, 2015)

\section{METODE PENELITIAN}

\section{Waktu dan Tempat Penelitian}

Penelitian dilaksanakan di Jakarta dan Bogor pada Juni 2017 hingga Juli 2017. Pemilihan tempat penelitian sengaja dipilih di dua lokasi tersebut karena pertimbangan bahwa Provinsi DKI Jakarta merupakan daerah dengan populasi yang padat dengan penduduk 10.177.924 jiwa merupakan pusat pemerintahan Indonesia, sehingga selain sebagai pusat pemerintahan, DKI Jakarta juga menjadi pusat transaksi ekonomi (Monica, 2013; BPS, 2017). Bogor dipilih karena merupakan daerah penyangga ibu kota Provinsi DKI Jakarta, sebagai pusat wisata nasional dimana terdapat agroindustri IKM sekaligus sebagai tempat pemasaran produk makanan (Rahman, 2010).

\section{Jenis dan Sumber Data}

Data penelitian diperoleh dari hasil wawancara dan pengisian daftar pertanyaan berupa kuisioner dari respon den penelitian. Wawancara pendahuluan dilakukan sebelum proses pengisian kuisioner. Pemilihan responden dilaksanakan hanya bagi konsumen yang secara rutin mengkonsumsi cokelat: setiap hari, dua kali dalam seminggu, seminggu sekali, satu kali dalam dua minggu, dan setiap bulan. Jenis data yang digunakan berupa data primer yang bersifat kualitatif dan kuantitatif.

\section{Tahapan Penelitian}

Gambar 2 merupakan tahapan yang dilakukan dalam penelitian ini yang dimulai dari analisis kepentingan atribut dalam membeli produk makanan cokelat berupa cokelat batangan (bar), cokelat roti, cokelat kue, cokelat permen, dan cokelat es krim. Atribut yang menjadi pertimbangan konsumen dalam pembelian makanan cokelat, selanjutnya dianalisis untuk mengetahui tingkat kepuasan dan ketidakpuasan setiap atribut yang dilakukan melalui wawancara dan pengisian kuisioner.

Metode importance performance analysis (IPA) untuk melakukan plotting posisi setiap atribut untuk mengetahui prioritas pengembangan atribut yang perlu dilakukan terhadap makanan cokelat oleh industri pengolahan.

\section{Dimensi Kualitas Cokelat}

Dimensi kualitas sensori yang digunakan pada penelitian ini adalah, taste (rasa), texture (tekstur), aroma, product appearance (penampilan produk) dan freshness (kesegaran produk). Taste diantaranya mengacu pada penelitian Voltz dan Beckett (1997); Luna et al. (2002); Nair (2013), Mankinde dan Akinoso (2014) serta Muresan et al. (2012). Texture diantaranya mengacu pada penelitian Voltz dan Beckett (1997); Ngang et al. (2014); Ilmi et al. (2016); Nair (2013); Mankinde dan Akinoso (2014); Ijah et al. (2014). Aroma diantaranya mengacu pada penelitian Voltz dan Beckett (1997); Muresan et al. (2012); Ijah et al. (2014); Ameh et al. (2013). Product appearance diantaranya mengacu pada penelitian Muresan et al.(2012); Marić et al. (2009). Freshness mengacu pada penelitian Nair (2013); Al-Tit (2015); Tzeng dan Chang (2011); Marić et al. (2009) dan Donkoh et al. (2012). Taste atau rasa merupakan kualitas sensoris yang paling penting dalam produk cokelat dimana citarasa susu, manis, asam dan lain-lain bergabung untuk memberi rasa yang unik dengan komposisi seimbang. Aroma coklat sangat menarik bagi kebanyakan orang, tetapi jika sudah terkontaminasi oleh bau busuk atau noda kimia produk bisa menjadi benar-benar tidak enak (Voltz dan Beckett, 1997). Health dipilih sebagai dimensi kualitas produk karena makanan yang sehat bergizi menunjukkan kualitas produk yang baik. Beberapa referensi untuk indikator health adalah Brunsø et al. (2002); Al-Tit (2015) serta Tzeng dan Chang (2011).

Kemasan (packaging) sebagai dimensi kualitas produk karena kemasan dari bahan yang baik mampu melindungi produk dengan baik dan dapat menjaga kualitas produk selama penyimpanan. Indikator kemasan mengacu pada beberapa referensi seperti Nair (2013); Marić et al. (2009). Variasi produk dimasukkan dalam dimensi kualitas produk mengacu pada Al-Tit (2015). 


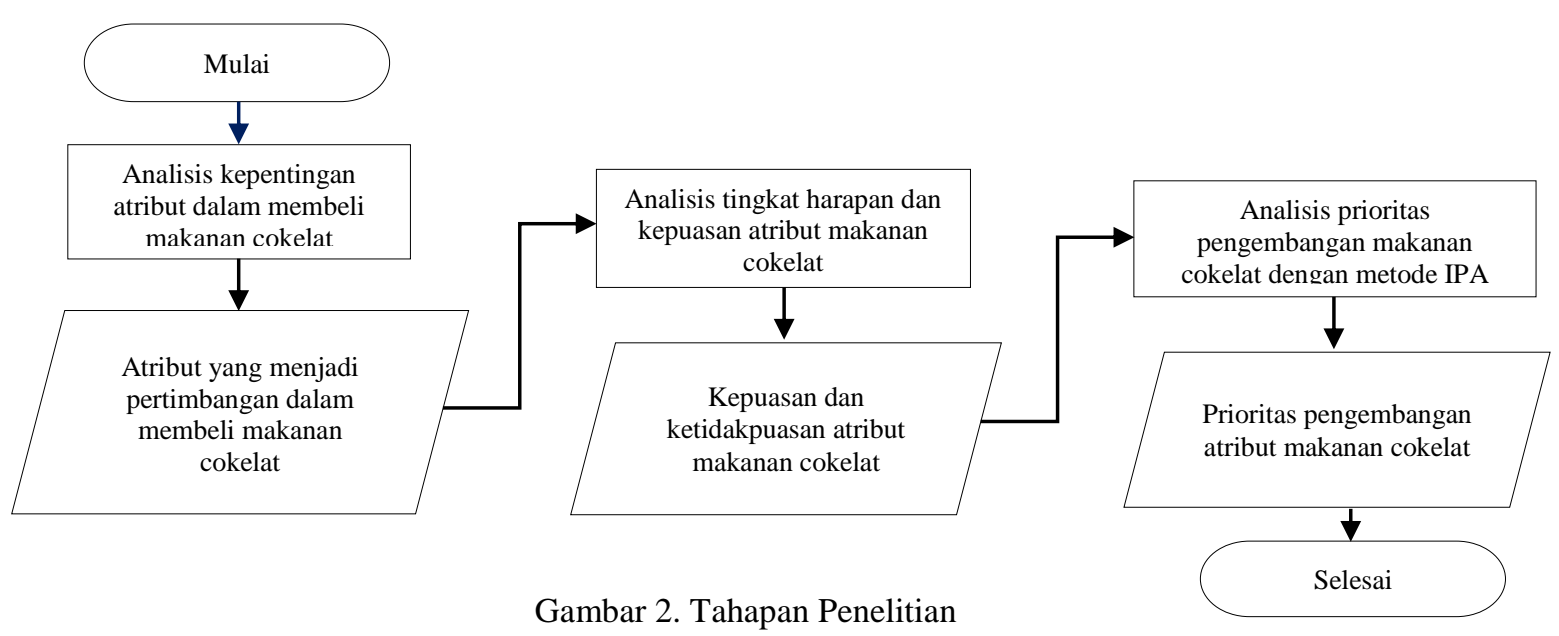

Kriteria konsumen yang dipilih untuk dijadikan responden adalah yang rutin mengonsumsi cokelat makanan: setiap hari, dua kali seminggu, sekali seminggu, setiap dua minggu, dan sekali sebulan. Sebanyak 500 responden yang memenuhi syarat dan melakukan pengisian kuisioner terdiri dari $122(24 \%)$ pria dan 378 (76\%) wanita. Responden dikelompokkan dalam lima kelompok umur: berusia $\leq 18$ tahun (22\%), berusia 19-25 tahun (36\%), berusia 26-40 tahun (23\%), berusia 41-65 tahun $(15 \%)$, dan berusia $\geq 66$ tahun $(4 \%)$. Berdasarkan profesi terdiri: pegawai swasta $(42 \%)$, Pegawai Negeri Sipil (15\%), wiraswasta $(22 \%)$, pelajar \& mahasiswa (15\%), ibu rumah tangga (4\%), dan profesi lainnya (2\%). Konsumen yang secara rutin mengonsumsi makanan cokelat diperoleh: setiap hari (6\%), dua kali seminggu (16\%), sekali seminggu (45\%), setiap dua minggu (5\%), sekali sebulan (28\%). Paper ini secara khusus menganalisis produk cokelat bar dan cokelat roti dan kue, sedangkan pembahasan mengenai produk makanan cokelat lainnya yaitu, permen cokelat dan es krim cokelat yang cenderung memiliki atribut sensori yang berbeda, dibahas dan dipublikasikan secara terpisah.

\section{HASIL DAN PEMBAHASAN}

Skala Likert pada kuisioner penilaian dan harapan produk makanan cokelat digunakan untuk mengukur tingkat kepuasan dan tingkat kepentingan konsumen. Skala kepuasan nilai yang digunakan adalah 1 sampai dengan 5, dengan skala jawaban dari "Sangat Tidak Puas" sampai pada jawaban "Sangat Puas". Skala pengukuran merupakan nilai yang akan diberikan konsumen melalui kuisioner yang tertera pada setiap atribut kualitas produk, sedangkan untuk tingkat kepentingan, juga dapat digunakan nilai 1 sampai dengan 5, namun untuk mengukurnya digunakan skala jawaban "Sangat Tidak Penting" sampai dengan "Sangat Penting".Tingkat kepentingan ini didasarkan pada persepsi konsumen terhadap tingkat kepentingan suatu atribut kepuasaan produk makanan cokelat. Gap analysis dilakukan untuk mengetahui perbedaan nilai performa dan harapan terhadap produk-produk makanan cokelat olahan khususnya cokelat bar, roti cokelat, kue cokelat, permen dan es krim cokelat.

Tanggapan responden pada tingkat kepentingan dan tingkat kepuasan produk cokelat ditampilkan pada Tabel 2. Kode pernyataan P1: Taste (rasa) produk enak, P2: Texture (keempukan) produk baik, P3: Aroma produk enak, P4: Product appearance (penampilan produk) baik dan menarik, P5: Portion (ukuran) produk baik dan sesuai, P6: Variety (variasi) produk banyak, P7: Freshness (kesegaran) produk baik, P8: Health (produk sehat bergizi), P9: Packaging (kemasan) produk baik dan menarik, P10: Price fairness (harga sesuai kualitas produk), dan P11: Discount (diskon) produk menarik.

Pada Tabel 2 dihitung frekuensi dari skor jawaban dan persentasenya serta dijumlahkan total skor serta skor idealnya. Berdasarkan hasil pengolahan yang ditampilkan pada tabel diatas, dapat dilihat bahwa skor total untuk produk roti pada tingkat kepentingan adalah 21.271 atau $77,34 \%$ dari skor ideal 27.500. Jumlah skor tersebut kemudian dimasukkan ke dalam garis kontinum.

Garis kontinum pada Gambar 3 terlihat skor total produk cokelat pada tingkat kepentingan berada pada rentang 68\%-84\% dengan demikian tanggapan responden mengenai produk cokelat pada tingkat kepentingan berada pada kategori "Penting".

Tanggapan responden pada tingkat kepuasan produk cokelat disajikan Tabel 3. Tabel 3 dapat di lihat bahwa skor total untuk produk roti pada tingkat kepuasan adalah 14.508 atau 53\% dari skor ideal 27.500. Jumlah skor tersebut kemudian dimasukkan ke dalam garis kontinum.

Garis kontinum pada Gambar 4 terlihat skor total produk cokelat pada tingkat kepentingan berada pada rentang $52 \%$ - 68\%, dengan demikian tanggapan responden mengenai produk cokelat pada tingkat kepuasan berada pada kategori kurang puas.

Persentase skor total tingkat kepuasan pada Tabel 3 menunjukkan angka 53\%, pada garis kontinum seperti terlihat pada Gambar 4, mengonfirmasi bahwa nilai tersebut pada rentang 
tingkat kepuasan 52\% sampai dengan 68\%. Hasil analisis tingkat kepentingan seperti terlihat pada Tabel 2 dan Gambar 3, menunjukkan bahwa keseluruhan atribut produk makanan cokelat merupakan hal yang penting bagi konsumen, sedangkan dari nilai kepuasan terlihat bahwa konsumen memberikan penilaian "Kurang Puas" terhadap produk-produk yang dikonsumsi.

Tabel 1. Nilai tingkat kepentingan dan tingkat kepuasan dengan skala Likert

\begin{tabular}{lclc}
\hline \multicolumn{1}{c}{ Harapan/Kepentingan } & \multicolumn{2}{c}{ Kepuasan/Performa } \\
\hline Jawaban & Skor & Jawaban & Skor \\
\hline Sangat Tidak Penting (STP) & 1 & Sangat Tidak Puas (STP) & 1 \\
Tidak Penting (TP) & 2 & Tidak Puas (TP) & 2 \\
Kurang Penting (KP) & 3 & Kurang Puas (KP) & 3 \\
Penting (P) & 4 & Puas (P) & 4 \\
Sangat Penting (SP) & 5 & Sangat Puas (SP) & 5 \\
\hline
\end{tabular}

Tabel 2. Tanggapan responden pada tingkat kepentingan produk cokelat

\begin{tabular}{|c|c|c|c|c|c|c|c|c|c|c|c|c|c|c|c|}
\hline \multirow{2}{*}{ No } & \multirow{2}{*}{ Pernyataan- } & \multicolumn{2}{|c|}{ SP } & \multicolumn{2}{|c|}{$\mathbf{P}$} & \multicolumn{2}{|c|}{$\mathbf{K P}$} & \multicolumn{2}{|c|}{ TP } & \multicolumn{2}{|c|}{ STP } & \multicolumn{2}{|c|}{ Jumlah } & \multirow{2}{*}{ Skor Total } & \multirow{2}{*}{ Skor Ideal } \\
\hline & & $\mathbf{f}$ & $\%$ & $\mathbf{f}$ & $\%$ & $\mathbf{f}$ & $\%$ & $\mathbf{f}$ & $\%$ & $\mathbf{f}$ & $\%$ & $\mathbf{f}$ & $\%$ & & \\
\hline 1 & P1 & 135 & 27 & 198 & 39.6 & 161 & 32.2 & 6 & 1.2 & 0 & 0 & 500 & 100 & 1962 & 2500 \\
\hline 2 & P2 & 107 & 21.4 & 244 & 48.8 & 140 & 28 & 9 & 1.8 & 0 & 0 & 500 & 100 & 1949 & 2500 \\
\hline 3 & P3 & 311 & 62.2 & 128 & 25.6 & 61 & 12.2 & 0 & 0 & 0 & 0 & 500 & 100 & 2250 & 2500 \\
\hline 4 & P4 & 74 & 14.8 & 314 & 62.8 & 106 & 21.2 & 5 & 1 & 1 & 0.2 & 500 & 100 & 1955 & 2500 \\
\hline 5 & P5 & 4 & 0.8 & 118 & 23.6 & 265 & 53 & 113 & 22.6 & 0 & 0 & 500 & 100 & 1513 & 2500 \\
\hline 6 & P6 & 335 & 67 & 84 & 16.8 & 78 & 15.6 & 3 & 0.6 & 0 & 0 & 500 & 100 & 2251 & 2500 \\
\hline 7 & P7 & 129 & 25.8 & 224 & 44.8 & 144 & 28.8 & 2 & 0.4 & 1 & 0.2 & 500 & 100 & 1978 & 2500 \\
\hline 8 & P8 & 116 & 23.2 & 249 & 49.8 & 127 & 25.4 & 6 & 1.2 & 2 & 0.4 & 500 & 100 & 1971 & 2500 \\
\hline 9 & P9 & 324 & 64.8 & 108 & 21.6 & 63 & 12.6 & 5 & 1 & 0 & 0 & 500 & 100 & 2251 & 2500 \\
\hline 10 & P10 & 11 & 2.2 & 129 & 25.8 & 274 & 54.8 & 86 & 17.2 & 0 & 0 & 500 & 100 & 1565 & 2500 \\
\hline 11 & P11 & 81 & 16.2 & 93 & 18.6 & 197 & 39.4 & 129 & 25.8 & 0 & 0 & 500 & 100 & 1626 & 2500 \\
\hline \multicolumn{14}{|c|}{ Jumlah Skor Total } & \multicolumn{2}{|c|}{21271} \\
\hline \multicolumn{14}{|c|}{ Persentase Skor Total } & \multicolumn{2}{|c|}{$77,34 \%$} \\
\hline
\end{tabular}

\section{$(77,34 \%)$}

\begin{tabular}{|c|c|c|c|c|}
\hline $\begin{array}{l}\text { SangatTidak } \\
\text { Penting }\end{array}$ & Tidak Penting/ & Kurang Penting & Penting & SangatPenting \\
\hline $20 \%$ & 52 & $68 \%$ & $84 \%$ & $\%$ \\
\hline
\end{tabular}

Gambar 3. Garis kontinum tingkat kepentingan

Tabel 3.Tanggapan responden pada tingkat kepuasanproduk cokelat

\begin{tabular}{|c|c|c|c|c|c|c|c|c|c|c|c|c|c|c|c|}
\hline \multirow{2}{*}{ No } & \multirow{2}{*}{ Pernyataan } & \multicolumn{2}{|c|}{ SP } & \multicolumn{2}{|c|}{$\mathbf{P}$} & \multicolumn{2}{|c|}{$\mathbf{K P}$} & \multicolumn{2}{|c|}{ TP } & \multicolumn{2}{|c|}{ STP } & \multicolumn{2}{|c|}{ Jumlah } & \multirow{2}{*}{ Skor Total } & \multirow{2}{*}{ Skor Ideal } \\
\hline & & f & $\%$ & f & $\%$ & f & $\%$ & f & $\%$ & f & $\%$ & f & $\%$ & & \\
\hline 1 & P1 & 19 & 3.8 & 79 & 15.8 & 89 & 17.8 & 195 & 39 & 118 & 23.6 & 500 & 100 & 1186 & 2500 \\
\hline 2 & P2 & 68 & 13.6 & 40 & 8 & 83 & 16.6 & 186 & 37.2 & 123 & 24.6 & 500 & 100 & 1244 & 2500 \\
\hline 3 & P3 & 25 & 5 & 59 & 11.8 & 58 & 11.6 & 195 & 39 & 163 & 32.6 & 500 & 100 & 1088 & 2500 \\
\hline 4 & P4 & 69 & 13.8 & 50 & 10 & 13 & 2.6 & 216 & 43.2 & 152 & 30.4 & 500 & 100 & 1168 & 2500 \\
\hline 5 & P5 & 1 & 0.2 & 0 & 0 & 22 & 4.4 & 144 & 28.8 & 333 & 66.6 & 500 & 100 & 692 & 2500 \\
\hline 6 & P6 & 33 & 6.6 & 56 & 11.2 & 32 & 6.4 & 235 & 47 & 144 & 28.8 & 500 & 100 & 1099 & 2500 \\
\hline 7 & P7 & 66 & 13.2 & 74 & 14.8 & 25 & 5 & 115 & 23 & 220 & 44 & 500 & 100 & 1151 & 2500 \\
\hline 8 & P8 & 26 & 5.2 & 80 & 16 & 86 & 17.2 & 140 & 28 & 168 & 33.6 & 500 & 100 & 1156 & 2500 \\
\hline 9 & $\mathrm{P9}$ & 13 & 2.6 & 118 & 23.6 & 31 & 6.2 & 117 & 23.4 & 221 & 44.2 & 500 & 100 & 1085 & 2500 \\
\hline 10 & P10 & 394 & 78.8 & 74 & 14.8 & 5 & 1 & 26 & 5.2 & 1 & 0.2 & 500 & 100 & 2334 & 2500 \\
\hline 11 & $\mathrm{P} 11$ & 395 & 79 & 59 & 11.8 & 6 & 1.2 & 36 & 7.2 & 4 & 0.8 & 500 & 100 & 2305 & 2500 \\
\hline \multicolumn{14}{|c|}{ Jumlah Skor Total } & \multicolumn{2}{|c|}{14508} \\
\hline \multicolumn{14}{|c|}{ Persentase Skor Total } & \multicolumn{2}{|c|}{53} \\
\hline
\end{tabular}

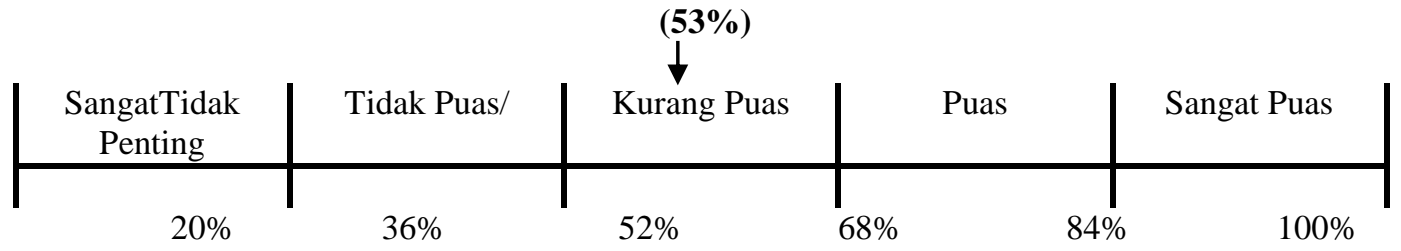

Gambar 4. Garis kontinum tingkat kepuasan/performa 
Gambar 5 menunjukkan bahwa atribut yang berada pada kuadran A, merupakan item-item yang perlu diperbaiki dan menjadi prioritas untuk meningkatkan kinerjanya. Atribut yang berada pada kuadran B menunjukkan bahwa kinerjanya sudah bagus dan perlu dijaga atau dipertahankan. Kuadran C tidak menjadi prioritas untuk ditingkatkan, sedangkan atribut yang berada pada kuadran D berarti kondisinya sudah berlebih dari perspektif konsumen dan tidak perlu lagi ditingkatkan.

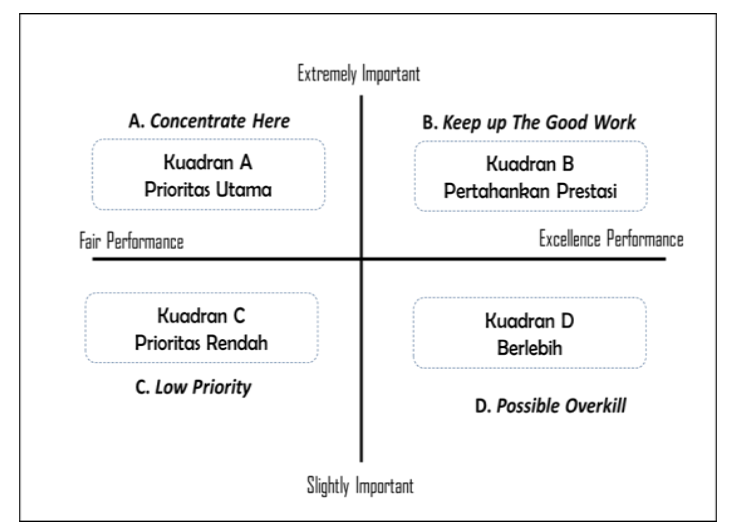

Gambar 5. Matriks importance performance analysis-IPA (Sumber: Martilla \& James, 1977)

Analisis IPA (Importance Performance Analysis)

Terdapat total 11 indikator untuk produk cokelat yang dianalisis dengan nilai kepentingan dan performa seperti terlihat pada Tabel 4. Gambar 6 merupakan plotting terhadap harapan dan kepuasan/performa produk makanan cokelat, yang menampilkan kode dan posisi indikator untuk diagram kartesius IPA produk cokelat.

Pada diagram kartesius IPA untuk produk roti (Gambar 5) dapat diketahui posisi indikatorindikator yang ditampilkan pada Tabel 5. Pada analisis IPA, Taste, Texture, Aroma, Product Appearance, Variety, Freshness, Health dan Packaging masuk dalam diagram A (concentrate here). Portion berada pada kuadran C (possible overkill). Price fairness, discount berada pada kuadran D (low priority). Implikasi manajerial dari Gambar 6 adalah bahwa atribut Taste, Texture, Aroma, Product Appearance, Variety, Freshness, Health dan Packaging sangat penting untuk dilakukan prioritas perbaikan atau peningkatan, sedangkan item-item lainnya yang berada di luar kuadran A tidak menjadi prioritas untuk ditingkatkan. Pengembangan produk pada industri makanan berbasis IPA khususnya produk cokelat sangat jarang dipublikasikan. Metode quality function deployment (QFD) diterapkan oleh beberapa food industry.

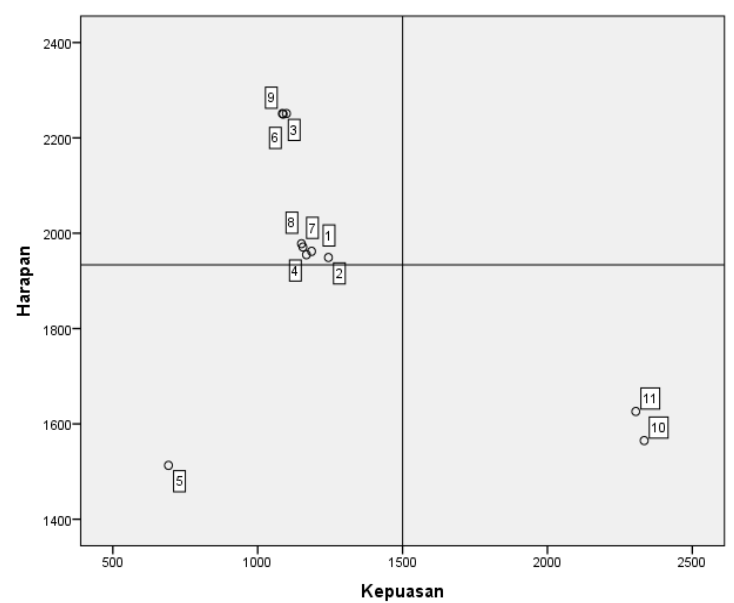

Gambar 6. Kode dan posisi indikator untuk analisis IPA produk cokelat

Penelitian yang fokus pada penerapan QFD pada industri pemrosesan makanan dilakukan oleh Mazur (2008) yang menetapkan item-item customer needs: (i) healthy, (ii) taste, (iii) appearance, (iv) texture, dan lainnya.

Tabel 4. Kode dan posisi indikator untuk diagram kartesius IPA produk cokelat

\begin{tabular}{|cclrr}
\hline Variabel & $\begin{array}{c}\text { Kode atribut } \\
\text { IPA }\end{array}$ & Atribut & $\begin{array}{c}\text { Kepentingan } \\
\text { (harapan) }\end{array}$ & $\begin{array}{c}\text { Penilaian } \\
\text { (performa) }\end{array}$ \\
\hline 1 & Taste & 3,924 & 2,372 \\
& 2 & Texture & 3,898 & 2,488 \\
& Aroma & Product Appearance & 3,91 & 2,176 \\
& 4 & Portion & 3,026 & 2,336 \\
& 5 & Variety & 4,502 & 1,384 \\
Produk & Freshness & 3,956 & 2,198 \\
& 7 & Health & 3,942 & 2,302 \\
& 8 & Packaging & 4,502 & 2,312 \\
& 9 & Price fairness & 3,13 & 2,17 \\
& 10 & Discount & 3,252 & 4,668 \\
& 11 & & 4,61
\end{tabular}


Paiva dan Pinto (2011) mengeksplorasi the voice of the customer menjadi primary level dan secondary level dimana dalam hal ini secondary level merupakan penjabaran yang lebih detail dari primary level. Primary level pertama: "terlihat bagus" yang dijabarkan dalam secondary level menjadi (i) tekstur yang baik, (ii) warnanya bangus, (iii) aspek menarik. Primary level kedua: "lezat" yang dijabarkan dalam secondary level menjadi (i) aroma yang menyenangkan, dan (ii) rasa menyenangkan. Primary level ketiga: "kepuasan dalam mempersiapan", yang dijabarkan dalam secondary level menjadi (i) sepenuhnya. Primary level keempat: "aman", yang dijabarkan dalam secondary level menjadi (i) aman. Primary level kelima: "sehat", yang dijabarkan dalam secondary level menjadi (i) sehat. Keseluruhan item pada secondary level juga diterjemakan dengan sangat spesifik pada tertiary level. Wangcharoen et al. (2006) menetapkan hanya empat faktor yang menjadi customer needs dalam penelitiannya yaitu: appearance, aroma, taste, dan texture.

\section{KESIMPULANDAN SARAN}

\section{Kesimpulan}

Kesimpulan yang diperoleh dari penelitian ini adalah: (1) terdapat 11 atribut sensori yang menjadi pertimbangan konsumen dalam memutuskan membeli produk-produk makanan cokelat, (2) berdasarkan analisis garis kontinum diketahui bahwa kesebelas atribut sensori tersebut dari perspektif konsumen masuk kategori "Penting" pada tingkat kepentingan, dan kategori "Kurang Puas" pada kategori tingkat kepuasan atau performa, (3) analisis IPA menunjukkan bahwa atribut yang perlu menjadi perhatian pengembangan adalah yang berada pada kuadran A yaitu: Taste, Texture, Aroma, Product Appearance, Variety, Freshness, Health dan Packaging. Industri pengolahan produk cokelat skala IKM memiliki keterbatasan sumber daya dalam mengembangkan produknya, apabila dibandingkan dengan produsen cokelat industri besar. Mengetahui keinginan konsumen melalui kuisioner dan dianalisis dengan IPA, sangat perlu dilakukan oleh IKM agar produk-produk baru yang dikembangkan dapat memenuhi kebutuhan dan keinginan konsumen.

\section{Saran}

Atribut produk merupakan item-item penting yang menjadi pertimbangan konsumen dalam memutuskan membeli produk cokelat. Penelitian ini memberikan gambaran bagi penguatan industri hilir khususnya industri kecil menengah (IKM) dapat mengembangkan produk-produk cokelat olahan berdasarkan atribut-atribut tersebut khususnya yang masih berada pada kuadran A yang berbasis pada preferensi konsumen.Penelitian selanjutnya dapat dilakukan dengan konsentrasi melakukan riset konsumen pada salah satu IKM pengolahan cokelat di setiap daerah, sehingga hasil kuisioner dari konsumen dapat lebih representatif bagi pengembangan produk-produk cokelat di daerah tersebut.

\section{DAFTAR PUSTAKA}

Afoakwa EO. 2008. Cocoa and chocolate consumption- Are there aphrodisiac and other benefits for human health? South African Journal Clinical Nutrition. 21(3): 107-113.

Alberts HC dan Cidell JL. 2006. Chocolate consumption, manufacturing and quality in Western Europe and the United States. Geography. 91(3): 218-226.

Al-Tit AA. 2015. The effect of service and food quality on customer satisfaction and hence customer retention. Asian Social Science.11(23):129-140.

Ameh MO, Gernah DI, Igbabul BD. 2013. Physicochemical and sensory evaluation of wheat bread supplemented with stabilized undefatted rice bran. Food and Nutrition Sciences. 4(09): 43-52.

Bordiga M, Locatelli M, Travaglia F, Coisson JD, Mazza G, Arlorio M. 2015. Evaluation of the effectof processing on cocoa polyphenols: antiradical activity, anthocyanins and procyanidins profiling from raw beans to chocolate. International Journal of Food Science and Technology.50: 840-848.

Corti R, Flammer AJ, Hollenberg NK, Lüscher TF. 2009. Cocoa and cardiovascular health. Contemporary Reviews in Cardiovascular Medicine. 119 :1433-1441.

Donkoh SA, Quainoo AK, Cudjoe E, Kaba NC. 2012. Customer satisfaction and perceptions about food services on the University for Development Studies Campus, Ghana. African Journal Food Science, 6(8): 216-223.

Erukainure OL, Egagah TI, Bolaji PT, Ajiboye AJ. 2010. Development and quality assessment of date chocolate products. American Journal Food Technology, 5(5): 324-330.

Euromonitor International: http://www.euromonitor. com/ [diakses pada 1 Maret 2017].

Food and Agriculture Organization (FAO): www.fao.org/ [diakses pada 18 Februari 2017].

Gilbert LC. 2006. Value Chain Analysis and Market Power in Commodity Processing with Application to the Cocoa and Coffee Sectors. FAO Workshop on Governance, Coordination and Distribution Along Commodity Value Chain, Rome, Italy. http://web.unitn.it/files/5 06 gilbert.pdf [3 June 2017].

[ICCO] International Cocoa Organization. https://www.icco.org/ 
Hii CL, Law CL, Suzannah S, Misnawi, Cloke M. 2010. Polyphenols in cocoa (Theobroma cacao L.). Asian Journal Food and AgroIndustry. 2(04): 702-722.

Ijah UJJ, Auta HS, Aduloju MO, Aransiola SA. 2014. Microbiological, nutritional, and sensory quality of bread produced from wheat and potato flour blends. International Journal Food Science. 2014: 1-6.

International Cocoa Organization (ICCO).https:/ /www.icco.org/ [7 Januari 2018].

Keen CL. 2001. Chocolate: Food as Medicine/Medicine as Food. Journal the American College of Nutrition. 20 (5): 436439.

[Kementan] Kementerian Pertanian. 2016. Direktorat Jenderal

Perkebunan.http://ditjenbun.pertanian.go.id/ti nymcpuk/gambar/file/statistik/2017/BukuKakao-2015- 2017.pdf $\quad[15$ Januari 2018].

Kongor JE, Hinneh M, Walle DV, Afoakwa EO. 2002. Factors influencing quality variationin cocoa (Theobroma cacao) bean flavour profile-A review. Food Research International Journal. 82: 44-52.

LunaF, Crouzillat D, CirouL, Bucheli P. 2002. Chemical composition and flavor $\mathrm{O}$ Ecuadorian cocoa liquor. Journal Agricultural Food Chemistry, Washington. 50 (12): 3527-3532.

Makinde FM dan Akinoso R. 2014. Physical, nutritional and sensory qualities of bread samples made with wheat and black sesame (Sesamum indicum Linn) flours. International Food Research Journal. 21(4): 1635-1640.

Marić A, Arsovski S, dan Mastilović J. 2009. Contribution to the improvement of products quality in baking industry. International Journal for Quality Research. 3(3): 1-8.

Mazur GH. 2008. QFD in the Food Processing Industry. QFD Institute. http://www.mazur.net/works/Mazur\%202008 \%20QFD\%20in\%20the\%20Food\%20Process ing\%20Industry.pdf. [8 August 2017].

McShea A, Puig ER, Munro SB, Casadesus G, Castell M, Smith MA. 2008. Clinical benefit and preservation of flavonols in dark chocolate manufacturing. Nutrition Reviews. 66(11): 630-641.

Monica V. 2013. Analisis kepuasan dan loyalitas konsumen anomali coffee di Kemang, Jakarta Selatan. [Skripsi]. Bogor: Institut Pertanian Bogor.

Muresan C, Stan L, Man S, Scrob S, Muste S. 2012. Sensory evaluation of bakery products and its role in determining of the consumer preferences. Journal Agroalimentary Process. Technol. 18(4): 304-306.

Nair S. 2013. Assessing Customer Satisfaction and Brand Awareness of Branded Bread. IOSR Journal Business and Management.12(2): 13-18.

Othman A, Ismail A, Ghani A, Adenan I. 2007. Antioxidant capacity and phenolic content of cocoa beans. Food Chemistry.100(4):15231530.

Osakabe N, Yamagishi M, Sanbongi C, Natsume M, Takizawa T, dan Osawa T. 1998. The antioxidative substances in cacao liquor. Jounal Nutrition Science and Vitaminology. 44: 313-321.

Paiva CL dan Pinto ALD. 2011. Employment of the Quality Function Deployment (QFD) Method in the Development of Food Products. University Federal of Minas Gerais.https://www.intechopen.com/books/sc ientific-health-and-social-aspects-of-thefood-industry/employment-of-the-qualityfunction-deployment-qfd-method-in-thedevelopment-of-food-products. [2 July 2017].

Pratiwi NA, Harianto, dan Daryanto A. 2017. Peran agroindustri hulu dan hilir dalam perekonomian dan distribusi pendapatan di Indonesia. Jurnal Manajemen \& Agribisnis. 14 (2): 127-137.

Panlibuton H dan Meyer M. 2004. Value Chain Assessment: Indonesia Cocoa, Accelerated Microenterprise Advancement Project (AMAP) Report, USAID. pdf.usaid.gov/pdf_docs/Pnadh789.pdf [diakses pada 10 Januari 2018].

Rahman AAA. 2010. Potensi pengembangan situ di Kota Bogor sebagai objek wisata. [Tesis]. Semarang: Universitas Diponegoro.

Syahruddin N dan Kalchschmidt M. 2012. Traceability in the Cocoa Supply Chain: An Indonesian Context. Proceedings of POMS 23rd Annual Conference "Socially Responsible Operations", Chicago, IL, USA.

Tzeng GH dan Chang HF. 2011. Applying importance-performance analysis as a service quality measure in food service industry. Journal Technology Management and Innovation. 6(3):106-115.

Verna R. 2013. The history and science of chocolate. Malaysian Journal Pathol. 35(2):111-121.

Voltz M dan Beckett ST. 1997. Sensory of chocolate. The manufacturing confectioner. 77: 49-53. 